\title{
Testing the Environmental Kuznets Curve Hypothesis for Turkey: The Role of Clean Energy Consumption and Ecological Footprint
}

Suleyman Yurtkuran ( $\nabla$ suleymanyurtkuran@hotmail.com )

Ministry of Education, Ortahisar/Trabzon

\section{Research}

Keywords: EKC hypothesis, Ecological footprint, Clean energy consumption, Economic growth, Structural changes, Turkey

Posted Date: December 11th, 2020

DOI: https://doi.org/10.21203/rs.3.rs-124967/v1

License: (c) (i) This work is licensed under a Creative Commons Attribution 4.0 International License.

Read Full License 
Testing the Environmental Kuznets Curve Hypothesis for Turkey: The Role of Clean Energy Consumption and Ecological Footprint

\section{Suleyman YURTKURAN}

Ministry of Education, 61040, Trabzon, Turkey.

\section{Correspondence author information:}

E-mail: suleymanyurtkuran@hotmail.com

Phone: +90 5079914860

Fax: +90462 8813024

Address: Ministry of Education, Ortahisar/Trabzon, Turkey 


\section{Testing the Environmental Kuznets Curve Hypothesis for Turkey: The Role of Ecological Footprint}

Abstract: This study aims to investigate the dynamic relationship between income, clean
energy consumption, exports, imports, urbanization and ecological footprint for Turkey from 1973 to 2015 using the environmental Kuznets curve hypothesis. The long-term coefficients derived from the ARDL approach demonstrate that import increase the ecological footprint, whereas urbanization and clean energy consumption do not have an impact on environmental pollution in the long-term. In addition, the 2001 dummy variable is negative and statistically significant. The crisis in 2001 slowed down the economic growth rate. This situation also caused reduction of environmental pollution. Moreover, the long run estimates indicate that the EKC hypothesis is valid in Turkey. However, the turning point of per capita income was calculated as $\$ 16,045$ that outside of the analyzed period. As economic activities increase, human pressure on nature continues to increase. Consequently, the only factor that reduces the ecological footprint has been determined as exports. In contrast, economic growth and clean energy consumption cannot be used as a tool to reduce the ecological footprint. Turkey needs a higher level of per capita income than the threshold level to improve environmental quality.

Keywords: EKC hypothesis, Ecological footprint, Clean energy consumption, Economic growth, Structural changes, Turkey.

\section{Introduction}


The 21st century is witnessing an increase in the average global temperature due to the climate change and global warming throughout the world. The five-year average air temperature values for the period between 2013 and 2017 were at a record level, $0.4^{\circ} \mathrm{C}$ above the $1981-$ 2010 norms and $1.0^{\circ} \mathrm{C}$ above the pre-industrial period (World Meteorological Organization, 2017). This increase is expected to be $1.4-5.8^{\circ} \mathrm{C}$ by 2100 (Steinfeld et al., 2006). Greenhouse gas $(\mathrm{GHG})$ emissions is the main factor causing temperature increase. Since the pre-industrial period, there has been a global rise of $70 \%$ between 1970 and 2004 in GHG emissions, particularly carbon dioxide $\left(\mathrm{CO}_{2}\right)$, as a result of industrial and agricultural activities (IPCC, 2007). The increase in the atmospheric density of these gases causes permanent damage (IPCC, 2014). $\mathrm{CO}_{2}$ emissions make up about $70 \%$ of GHG in the world (Yilanci and Pata, 2020), and represent the largest share of human-induced adverse environmental impacts at the global level (Baek, 2016).

The widespread use of fossil fuels, which constitute a large part of the total global energy supply, have a limited capacity, and are a result of human activities, brings along negative environmental factors. Because of the fossil fuels used, $\mathrm{CO}_{2}$ emission in the atmosphere increases and global warming occurs. The transition to renewable energy sources would reduce the consumption of these fuels, increase energy security, and reduce $\mathrm{CO}_{2}$ emission. Renewable energy sources contribute to the reduction of fossil fuel consumption (Apergis and Payne, 2012). Thus, renewable energy is an important source of interest for both developed and developing countries.

There are many studies investigating the relationship between $\mathrm{CO}_{2}$ emissions and economic growth (see Zoundi, 2017; Pata, 2019). However, $\mathrm{CO}_{2}$ emissions are only one of the environmental pollution indicators (Destek and Sarkodie, 2019). In addition to this pollution indicator, resource stocks including forest land, mining and oil are also under great pressure. Rees (1992) and Wachernagel and Rees (1996) developed the ecological footprint (EF) 
calculated that is a highly effective metric of global sustainability. EF monitor the combined effect of anthropogenic pressures by following various human activities and can be used to understand environmental degradation and find solutions to these problems (Galli et al., 2012).

In measuring the EF, human-demanded aspects include plant-based nutrients, fiber foods, large and small ruminants, seafood, forest products such as timber, and construction. It also measures the extent to which forests absorb carbon emissions from fossil fuels (Galli et. al. 2012). While consuming these resources, it is vital to ensure the continuance of the life cycle. The EF contains six components: cropland, grazing land, forest products, fishing grounds, builtup land, and CF (Ulucak and Bilgili, 2018). The CF has the highest share among these six components, demonstrating a lack of the ecological capacity necessary to combat $\mathrm{CO}_{2}$ emissions and highlighting the importance of reducing emissions (Wieddman and Minx, 2008). The EF calculation is based on an estimate of how much of the world's forestry can absorb and cleanse human-sourced $\mathrm{CO}_{2}$ given how, as biologically productive forest area rises, the intensity of $\mathrm{CO}_{2}$ emissions into the atmosphere decreases. $\mathrm{EF}$ is used to measure how many resources the world's population demands from the ecosystem and how much it needs to recover (Caviglia-Harris et al., 2009). Biocapacity represents the natural resource supply and EF indicates the natural resource demand (Galli et. al., 2012). EF and biocapacity are expressed in a common unit called global hectares (gha) which represents the production capacity of one hectare of land over the world's average productivity. The biocapacity of natural resources requires their state of renewal (existence) to be equal to or higher than the $\mathrm{EF}$, thus ensuring a sustainable habitat. when If EF exceeds biocapacity, then ecological deficit occurs. Otherwise, ecological reserve occurs. Since the EF reflects environmental problems extensively, reliable and powerful findings can be obtained by using this indicator when examining the relationships between environmental pollution and economic growth. 


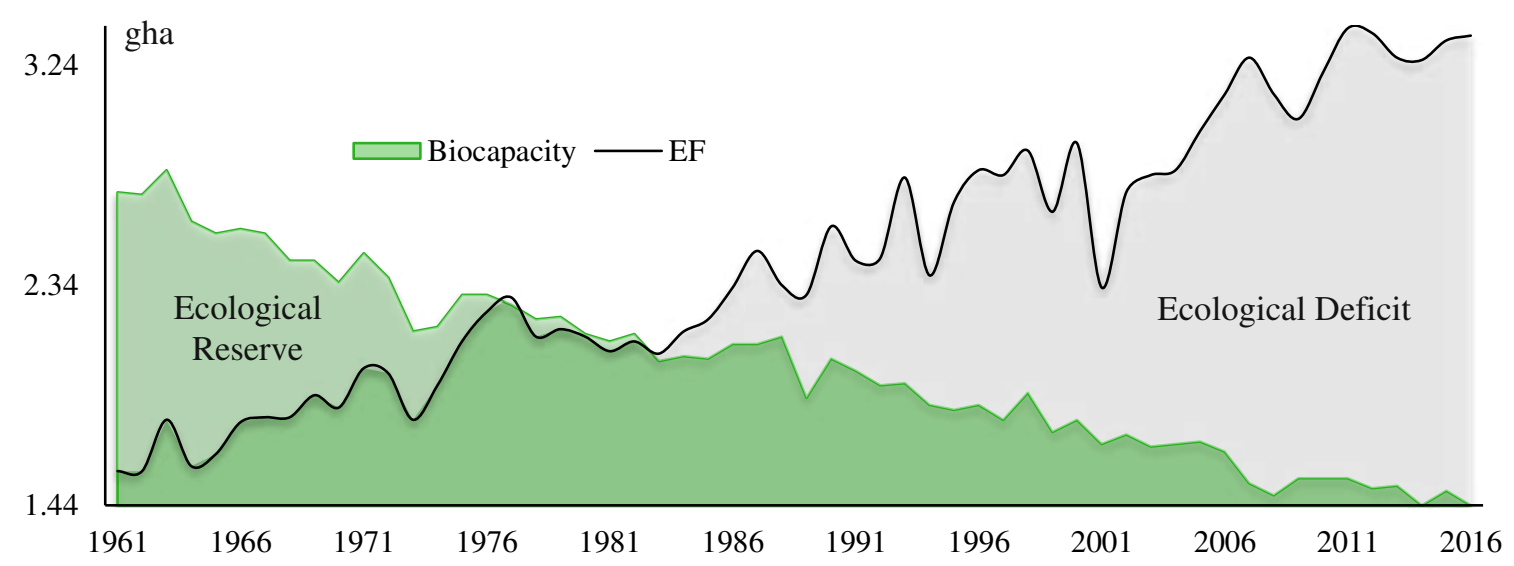

Fig 2. EF and Biocapacity in Turkey.

Figure (2) demonstrates the EF and biocapacity values in Turkey. In this country, the EF increased by approximately $113 \%$ over 56 years. At that time, biocapacity decreased $47 \%$. The EF has increased almost twice in the relevant period. After 1983, the country has continuously demonstrated an ecological deficit. Turkey's ecological deficit was 0.03 gha in 1983 , rising to 1.92 gha by 2016, indicating that humans have placed serious pressure on nature in Turkey, and urgent measures must be taken to solve this problem.

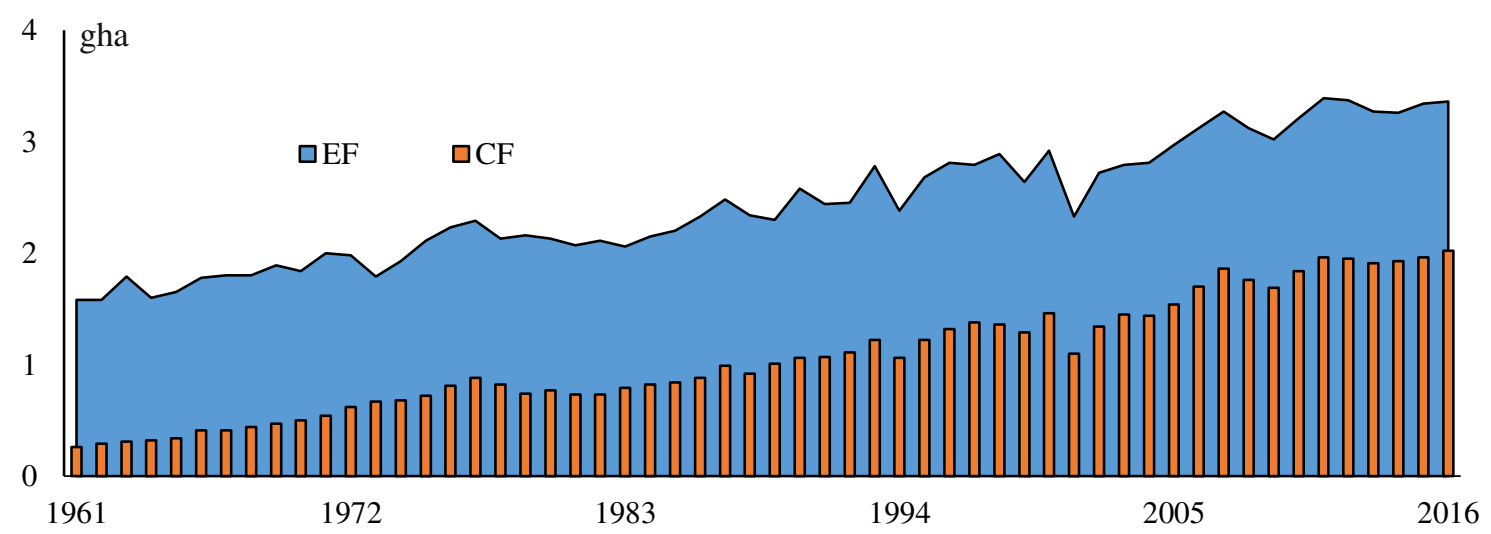

Figure 3. EF and CF in Turkey.

Figure (3) illustrates the EF and CF values in Turkey. The CF was 0.26 gha (16\% of EF) in 1961 , increasing yearly to 2.02 gha $(60 \%$ of $\mathrm{EF})$ by 2016 , thus demonstrating that the CF constitutes the largest proportion of the EF in Turkey, causing enormous environmental problems. 
Grossman and Krueger (1991) conducted the first study focusing on pollution-income nexus and Panayotou (1993) was the first researcher to use the term "environmental Kuznets curve (EKC)." The EKC hypothesis, which states that economic growth positively affects environmental quality in the long term, has been a prominent issue for researchers since then (Tamazian et al., 2009). This hypothesis assumes that inefficient use of resources, along with industrialization in the first phases of development, will result in increased environmental pollution but that after a certain turning point, society can establish environmental organizations, demand a clean environment, and reduce environmental pollution through the use of environmentally friendly technologies. Governments ignore increased natural resources consumption through rapid growth because they consider the country's economic prosperity and growth to be their main objectives (Munasinghe, 1999). In developing economies where agriculture-based growth takes place, increasing production and income levels become the primary targets of the first stage of economic growth, along with industrialization. Therefore, while economic growth is occurring, there is an increase in environmental pollution due to the use of non-clean technologies and the consumption of natural resources. In developed countries, in contrast, as advanced technologies are introduced, a transition occurs from an industrial sector manufacturing heavy industrial product to an information- and technology-intensive service sector.

\section{Literature Review}

Grossmann and Krueger (1991) tested the effect of per capita economic growth on suspended particulate matter, sulfur dioxide, and dark matter concentration. In the following years, other variables causing environmental pollution have been included in the analysis. In addition to income, variables such as imports (Bouznit and Pablo-Romero, 2016; Rafindadi, 2016; Pata, 2018c), exports (Bouznit and Pablo-Romero, 2016; Zambrano- Monserrate et al., 2017; Apergis et. al., 2018; Pata, 2018c), foreign direct investment (Pao and Tsai, 2011; Tang and 
Tan, 2015) and urbanization (Abdallh and Abugamos, 2017; Sbia et. al., 2017) were also utilized in research.

One variable used in the studies is the energy consumption influenced by human activities that consists of the largest proportion of environmental pollution. Ang (2007) for France, Soytas et. al. (2007) for United States, Jalil ve Mahmud (2009) for China, Jalil and Feridun (2011) for China, Nasir and Rehman (2011) for Pakistan, Hossain (2012) for Japan, Kohler (2013) for South Afrika and Shahbaz et al. (2017) for Australia found that energy consumption leads to higher environmental pollution. The consumption of renewable energy sources has been a variable used in analyzing the EKC hypothesis in recent years. In some research, it is evident that renewable energy sources reduce $\mathrm{CO}_{2}$ emissions. Shafiei and Salim (2014) for 29 OECD countries; Azlina et al. (2014) for Malaysia; Menegaki and Tsagarakis (2015) for 33 European Union member and candidate countries; Sugiawan and Managi (2016) for Indonesia; OnaterIsberk (2016) for 27 OECD countries; Danish et al. (2017) for Pakistan; Pata (2018c) for Turkey; Gill et al. (2018) for Malaysia; Naz et. al. (2018) for Pakistan; Qiao et. al. (2019) for G20 countries; Chen et. al. (2019) for China and Kahia et. al. (2019) for 12 North African and Middle Eastern countries concluded that renewable energy consumption has a negative effect on environmental pollution. In addition, Ben Jebli et al. (2015) for 24 sub- Saharan countries and Pata (2018b) for Turkey indicate that renewable energy sources do not have an impact on $\mathrm{CO}_{2}$ emissions.

Recently, the ecological footprint has been included in the analysis of the EKC hypothesis. Bagliani et al. (2008) employed cross sectional, ordinary least squares (OLS) and weighted LS for 144 countries in 2001. Caviglia-Harris et al. (2009) used a panel fixed effect (FE), from 1961 to 2000 for 146 countries. Wang et al. (2013) performed a panel approach for 150 countries in 2005. Pablo-Romero and Sanchez-Braza (2017) employed panel multilevel mixed effects for 40 countries for the period of 1995-2009. Ozcan et. al. (2018) performed a bootstrap 
window rolling Granger causality test for Turkey covering the period of 1961-2013. The results of these six studies do not support the EKC hypothesis.

Ozturk et al. (2016) used a time series GMM and S-GMM from 1988 to 2008 for 144 countries. Their results verified the EKC hypothesis. Aşıcı and Acar (2016) performed a panel FE for 116 countries covering the period of 2004-2008 and their results verified the EKC hypothesis. Mrabet and Alsamara (2017) examined Qatar from the years 1980 to 2011 using ARDL, a bounds test and confirmed the EKC hypothesis. Charfeddine and Mrabet (2017) used a panel fully modified OLS (FMOLS) and a dynamic OLS (DOLS) from 1995 to 2007 for 15 Middle East and North African countries. Their results found an inverted U-shaped relationship between the EF and economic growth and they verified the EKC hypothesis. Charfeddine (2017) performed a Markov switching equilibrium model for Qatar covering the period of 19702015 and his results verified the EKC hypothesis. Destek et. al. (2018) used panel group-mean FMOLS, group-mean DOLS and a dynamic common correlated effect estimator from 1980 to 2013 for the 15 EU countries. Their results found an inverted U-shaped relationship between the EF and economic growth and they verified the EKC hypothesis. and their results did not verify the EKC hypothesis. Destek and Sarkodie (2019) employed an augmented mean group estimator and a heterogeneous panel causality method for 11 newly industrialized countries from the period of 1977 to 2013 and confirmed the EKC hypothesis. Yilanci and Ozgur (2019) examined G7 countries from the years 1970 to 2014 using a bootstrap panel causality test and they confirmed the validity of the EKC hypothesis in Japan and the USA.

To best of our knowledge, only three studies examine the effect of renewable energy on EF within the framework of the EKC. Al-Mulali et. al. (2015) examined 93 countries from the years 1980 to 2008 using a panel FE and a GMM. They verified the EKC hypothesis in upper middle- and high-income countries. They also concluded that renewable energy production increases EF. Bello et al. (2018) utilized ARDL method for Malaysia over the period of 1971- 
2016. They concluded that hydropower energy consumption reduces $\mathrm{CO}_{2}$ emissions, $\mathrm{EF}$ and $\mathrm{CF}$, and confirmed the validity of the EKC hypothesis for all environmental pollution indicators. Destek and Sinha (2020) performed various panel data methods from 1980 to 2014, and found that renewable energy consumption reduces EF in 24 OECD countries. The results of this study do not support the EKC hypothesis.

There are no studies in the literature investigating the impact of clean energy consumption on EF in Turkey. In addition, only Ozcan et al. (2018) examined the EKC hypothesis by including the EF as a dependent variable in the analysis. The authors used a causality test in their work. Moreover, most studies in the literature neglect the effects of structural changes on environmental pollution. This study aims to fill these gaps in the literature. To this end, we investigate the relationship between urbanization, imports, exports, EF and economic growth with a structural break in Turkey. We expect this study to contribute to the literature from various aspects such as using a more comprehensive indicator, taking into account the omitted variable problem and a structural change.

\section{Data and Model}

Annual data from 1973 to 2015 are used for the test the validity of the EKC hypothesis. The basic model is given by:

$$
\operatorname{lnEF_{t}}=\mu_{0}+\mu_{1} \ln Y_{t}+\mu_{2} \ln Y_{t}^{2}+\mu_{3} \operatorname{lnCEC} C_{t}+\mu_{4} \operatorname{lnEX_{t}}+\mu_{5} \ln I_{t}+\mu_{6} \ln \operatorname{lRB}_{t}+\varepsilon_{t}
$$

In Eq. 1, $\mathrm{EF}_{\mathrm{t}}$ represents the per capita ecological footprint (gha); $\mathrm{Y}_{\mathrm{t}}$ and $\mathrm{Y}_{\mathrm{t}}^{2}$ represent per capita gross domestic product (GDP) and the square of per capita GDP (constant 2010 US\$); $\mathrm{CEC}_{\mathrm{t}}$ stands for per capita clean energy consumption involving hydro, nuclear, geothermal, and solar energy (ktoe); $\mathrm{EX}_{\mathrm{t}}$ denotes export of goods and services (\% of GDP); $\mathrm{IM}_{\mathrm{t}}$ indicates imports of goods and services (\% of GDP); and $\mathrm{URB}_{\mathrm{t}}$ is urbanization (\% of total population). The data were collected by the World Development Indicators (World Bank, 2019), Global Footprint 
Network (2019) and the International Energy Agency (IEA, 2019). All series were converted into logarithmic form.

The coefficients $\mu_{1}$ and $\mu_{2}$ yield different results under the EKC hypothesis assumption. When $\mu_{1}=\mu_{2}=0$, there is no relationship between pollution and growth. When $\mu_{1}$ is negative and $\mu_{2}=0$, there is a monotonically decreasing; when $\mu_{1}$ is positive and $\mu_{2}=0$, there is a monotonically increasing linear relationship, respectively. When $\mu_{1}$ is negative and $\mu_{2}$ is positive, there is a $U$-shaped relationship. When $\mu_{1}$ is positive and $\mu_{2}$ is negative, there is an inverse- $U$ relationship, which indicates a valid EKC hypothesis. When there is an inverse- $U$ relationship, the formula $-\mu_{1} / 2 \mu_{2}$ is applied to calculate the turning-point value of the EKC hypothesis. This value is then converted from logarithmic form to monetary value. As clean energy sources and exports reduce EF, the coefficients $\mu_{3}$ and $\mu_{4}$ are expected to be negative, whereas the coefficients $\mu_{5}$ and $\mu_{6}$ are expected to be positive as imports, and urbanization increase EF.

\section{Methodology}

\subsection{Unit Root Tests}

Before the ARDL method is applied, unit root tests are required to prove the variables are not I(2). The Ng-Perron (2001) unit root test is the improved version of the Phillips-Perron (PP) (1988) unit root test. This unit root test provides more realistic results than the PP unit root test when autoregressive roots are close to one. However, traditional unit root tests may offer misleading results because they do not include structural breaks in the model. Therefore, we also used Clemente-Montanes-Reyes (CMR) (1998) unit root test that allows two endogenous structural breaks.

\subsection{ARDL Approach}


The ARDL method, introduced by Pesaran et al. (2001), is more advantageous than other cointegration tests in many aspects. In this method, the dependent variable must be stationary at the $\mathrm{I}(1)$, but explanatory variables can be stationary at the $\mathrm{I}(0)$ or $\mathrm{I}(1)$. In addition, the shortand long-term effects are evaluated simultaneously, series with a small number of observations can be used, and the endogeneity problem concerning other cointegration tests is solved.

$$
\begin{aligned}
& \Delta \operatorname{lnEF} F_{t}=\alpha_{0}+\sum_{j=1}^{k} \alpha_{1 k} \Delta \operatorname{lnEF} F_{t-i}+\sum_{j=0}^{1} \alpha_{2 k} \Delta \ln Y_{t-i}+\sum_{j=0}^{m} \alpha_{3 k}\left(\Delta \ln Y_{t-i}\right)^{2}+\sum_{j=0}^{n} \alpha_{4 k} \Delta \operatorname{lnCEC} C_{t-i} \\
& +\sum_{\mathrm{j}=0}^{\mathrm{p}} \alpha_{5 \mathrm{k}} \Delta \ln \mathrm{EX}_{\mathrm{t}-\mathrm{i}}+\sum_{\mathrm{j}=0}^{\mathrm{r}} \alpha_{6 \mathrm{k}} \Delta \ln \mathrm{IM}_{\mathrm{t}-\mathrm{i}}+\sum_{\mathrm{j}=0}^{\mathrm{s}} \alpha_{7 \mathrm{k}} \Delta \ln \mathrm{URB}_{\mathrm{t}-\mathrm{i}}+ \\
& +\varphi_{1} \operatorname{lnEF} \mathrm{t}_{\mathrm{t}-1}+\varphi_{2} \ln \mathrm{Y}_{\mathrm{t}-1}+\varphi_{3}\left(\ln \mathrm{Y}_{\mathrm{t}-1}\right)^{2}+\varphi_{4} \operatorname{lnREN}_{\mathrm{t}-1}+\varphi_{5} \ln \ln _{\mathrm{t}-1}+\varphi_{6} \operatorname{lnIM}_{\mathrm{t}-1}+\varphi_{7} \ln \operatorname{lRB}_{\mathrm{t}-1}+\varepsilon_{\mathrm{t}}
\end{aligned}
$$

In the unrestricted error-correction model presented in equation $2, \alpha_{0}$ stands for constant term; $\varepsilon_{\mathrm{t}}$ for error term; $\alpha_{1}, \alpha_{2}, \alpha_{3}, \alpha_{4}, \alpha_{5}, \alpha_{6}, \alpha_{7}$ are error-correction dynamics; $\varphi_{1}, \varphi_{2}, \varphi_{3}, \varphi_{4}, \varphi_{5}$, $\varphi_{6}, \varphi_{7}$ are the long-term coefficients; and k, $1, \mathrm{~m}, \mathrm{n}, \mathrm{p}, \mathrm{r}$ and s are optimal lag lengths determined by the Schwarz information criterion (SIC).

For the Case II (restricted intercept-no trend) and the Case III (unrestricted intercept and no trend), the null hypothesis of no cointegration $\mathrm{H}_{0}:\left(\alpha_{0}=\varphi_{1}=\varphi_{2}=\varphi_{3}=\varphi_{4}=\varphi_{5}=\varphi_{6}=\varphi_{7}=0\right)$, is tested against the alternative hypothesis $\mathrm{H}_{\mathrm{A}}:\left(\alpha_{0} \neq \varphi_{1} \neq \varphi_{2} \neq \varphi_{3} \neq \varphi_{4} \neq \varphi_{5} \neq \varphi_{6} \neq \varphi_{7} \neq 0\right)$. Although Pesaran et al. (2001) developed table critical values to assess test results in series with a large number of observations, Narayan (2005) created appropriate critical values for small samples. Because the present study involves 43 observations, Narayan's table values were taken as a basis to determine the significance of the F-statistics obtained at the end of the bounds test. When the obtained F-statistics is smaller than the lower bound $\mathrm{I}(0)$, the null hypothesis cannot be rejected. When the obtained F-statistics is higher than I(1), the alternative hypothesis is accepted, and it is determined that there is cointegration between the series. After this stage, the long- and short- 
term coefficients are estimated. Lastly, when the calculated F-statistics value is between I(0) and I(1), no definitive judgment can be made on whether there is cointegration. Thus, it is recommended to apply other cointegration tests.

We determined long-term coefficients in the second stage. In the third stage (the last stage), we formed equation 3, which is ECM based on the ARDL approach.

$$
\begin{aligned}
& \Delta \ln \mathrm{EF}_{\mathrm{t}}=\beta_{0}+\sum_{\mathrm{j}=1}^{\mathrm{a}} \beta_{1} \Delta \ln \mathrm{EF}_{\mathrm{t}-\mathrm{i}}+\sum_{\mathrm{j}=0}^{\mathrm{b}} \beta_{2} \Delta \ln \mathrm{Y}_{\mathrm{t}-\mathrm{i}}+\sum_{\mathrm{j}=0}^{\mathrm{c}} \beta_{3}\left(\Delta \ln \mathrm{Y}_{\mathrm{t}-\mathrm{i}}\right)^{2}+\sum_{\mathrm{j}=0}^{\mathrm{d}} \beta_{4} \Delta \ln \mathrm{CEC}_{\mathrm{t}-\mathrm{i}} \\
& +\sum_{\mathrm{j}=0}^{\mathrm{e}} \beta_{5} \Delta \ln \mathrm{EX}_{\mathrm{t}-\mathrm{i}}+\sum_{\mathrm{j}=0}^{\mathrm{f}} \beta_{6} \Delta \ln \mathrm{IM}_{\mathrm{t}-\mathrm{i}}+\sum_{\mathrm{j}=0}^{\mathrm{g}} \beta_{7} \Delta \ln \operatorname{lRB}_{\mathrm{t}-\mathrm{i}}+\varphi \mathrm{ECT}_{\mathrm{t}-1}+\mathrm{u}_{\mathrm{t}}
\end{aligned}
$$

In equation $3, \beta_{0}$ is constant term; $\beta_{1,2,3,4,5,6,7}$ are short-term coefficients; $\varphi$ is the coefficient of the error correction term (ECT), $\mathrm{u}_{\mathrm{t}}$ is the disturbance term and $\mathrm{a}, \mathrm{b}, \mathrm{c}, \mathrm{d}, \mathrm{e}, \mathrm{f}$ and $\mathrm{g}$ are optimal lag lengths. $\varphi$ is used to determine the extent to which the imbalance that occurred in the shortterm can be eliminated in the long-term.

\section{Empirical Results}

Table 1 presents the Ng-Perron unit root test result. The results demonstrate that EF and URB series are stationary at the level, whereas the other series are stationary at the first difference. The results obtained from these traditional tests may cause a lack of information about structural breaking points. Therefore, tests with structural breaks will make the results more reliable.

Table 1. Ng-Perron Unit Root Test Results

\begin{tabular}{|l|l|l|l|l|}
\hline Variables & MZa & MZt & MSB & MPT \\
\hline $\operatorname{lnEF}$ & $-19.045^{* *}$ & $-3.079^{* *}$ & $0.162^{* *}$ & $4.826^{* *}$ \\
\hline $\ln \mathrm{CEC}$ & -7.573 & -1.943 & 0.257 & 12.040 \\
\hline $\ln \mathrm{X}$ & -5.672 & -1.635 & 0.288 & 15.957 \\
\hline $\ln \mathrm{M}$ & -12.247 & -2.414 & 0.197 & 7.767 \\
\hline
\end{tabular}




\begin{tabular}{|l|l|l|l|l|}
\hline $\ln U R B$ & $-28.994 * * *$ & $-3.748^{* * *}$ & $0.129 * * *$ & $3.484 * * *$ \\
\hline $\ln \mathrm{Y}\left(\mathrm{Y}^{2}\right)$ & -7.590 & -1.778 & 0.234 & 12.365 \\
\hline$\Delta \ln \mathrm{EF}$ & -- & -- & -- & -- \\
\hline$\Delta \ln \mathrm{CEC}$ & $-20.409 * *$ & $-3.086^{* *}$ & $0.151^{* *}$ & $5.115^{* *}$ \\
\hline$\Delta \ln \mathrm{EX}$ & $-19.640^{* *}$ & $-3.129 * *$ & $0.159^{* *}$ & $4.668^{* *}$ \\
\hline$\Delta \ln \mathrm{M}$ & $-20.307 * *$ & $-3.186^{* *}$ & $0.157^{* *}$ & $4.492^{* *}$ \\
\hline$\Delta \ln \mathrm{URB}$ & -- & -- & -- & -- \\
\hline$\Delta \ln \mathrm{Y}\left(\ln \mathrm{Y}^{2}\right)$ & $-20.470^{* *}$ & $-3.198^{* *}$ & $0.156^{* *}$ & $4.458^{* *}$ \\
\hline
\end{tabular}

$\mathrm{Ng}$-Perron critical values; MZa, MZt, MSB and MPT respectively;

$1 \%$ significance level for $-23.80,-3.42,0.14$ and 4.03

$5 \%$ significance level for $-17.30,-2.91,0.17$ and 5.48

$* * *$ and $* *$ denote $1 \%$ and $5 \%$ significance level respectively.

In Table 2, the results of the CMR unit root test indicates that EX, IM and URB are stationary at their levels, whereas the other variables are stationary at the first difference. Given the results of the two-unit root tests, it is observable that the variables are stationary to different degrees. Therefore, the ARDL bounds test was conducted to determine the long-term relationship in the series.

Table 2. Clemente-Montanes-Reyes Structural Break Unit Root Test Results.

\begin{tabular}{|c|c|c|c|c|c|c|}
\hline \multirow[b]{2}{*}{ Variables } & \multicolumn{3}{|l|}{ Level } & \multicolumn{3}{|c|}{ First difference } \\
\hline & T-statistic & TB1 & TB2 & T-statistic & TB1 & TB2 \\
\hline \multirow[t]{2}{*}{$\operatorname{lnEF}$} & -2.800 & 2001 & & $-10.693 * *$ & 2000 & \\
\hline & -5.204 & 1988 & 2001 & $-8.124 * *$ & 1976 & 2000 \\
\hline \multirow[t]{2}{*}{$\operatorname{lnCEC}$} & -4.257 & 1985 & & $-7.213 * * *$ & 1987 & \\
\hline & -4.783 & 1985 & 2008 & $-7.377 * * *$ & 1987 & 2006 \\
\hline \multirow[t]{2}{*}{$\operatorname{lnEX}$} & -3.547 & 1978 & & $-5.866^{* *}$ & 1983 & \\
\hline & $-7.324 * * *$ & 1980 & 1992 & - & - & - \\
\hline \multirow[t]{2}{*}{$\operatorname{lnIM}$} & $-4.863 * *$ & 1978 & & - & - & - \\
\hline & $-6.725 * * *$ & 1978 & 1992 & - & - & - \\
\hline \multirow[t]{2}{*}{$\ln U R B$} & $-7.517 * * *$ & 1979 & & - & - & - \\
\hline & $-12.577 * * *$ & 1979 & 2000 & - & - & - \\
\hline \multirow[t]{2}{*}{$\ln Y\left(\ln Y^{2}\right)$} & 0.038 & 2001 & & $-5.375^{* *}$ & 2000 & \\
\hline & -1.733 & 1984 & 2002 & $-7.481 * * *$ & 2000 & 2008 \\
\hline
\end{tabular}

*** and ** denote significant at $1 \%$ and $5 \%$ levels respectively.

Given the bounds test results illustrated in Table 3, the calculated F-statistics is greater than Narayan's (2005) table critical values, therefore a cointegration relationship exist between the series.

Table 3. Bounds test results 


\begin{tabular}{|c|c|c|c|c|c|c|c|}
\hline \multicolumn{8}{|c|}{ Model } \\
\hline \multicolumn{4}{|c|}{ ARDL $(1,0,0,0,0,0,0)$} & \multicolumn{4}{|c|}{$\mathrm{k}=6$} \\
\hline \multicolumn{8}{|c|}{ F statistics } \\
\hline \multicolumn{4}{|c|}{ Case II } & \multicolumn{4}{|c|}{ Case III } \\
\hline \multicolumn{4}{|c|}{$7.376 * * *$} & \multicolumn{4}{|c|}{$7.102 * * *$} \\
\hline \multicolumn{8}{|c|}{ Table critical values } \\
\hline \multicolumn{2}{|l|}{$1 \%$} & \multicolumn{2}{|l|}{$5 \%$} & \multicolumn{2}{|l|}{$1 \%$} & \multicolumn{2}{|l|}{$5 \%$} \\
\hline $\mathrm{I}(0)$ & $\mathrm{I}(1)$ & $\mathrm{I}(0)$ & $\mathrm{I}(1)$ & $\mathrm{I}(0)$ & $\mathrm{I}(1)$ & $\mathrm{I}(0)$ & $\mathrm{I}(1)$ \\
\hline 3.540 & 4.931 & 2.591 & 3.766 & 3.790 & 5.411 & 2.764 & 4.123 \\
\hline
\end{tabular}

$\mathrm{k}$ is number of independent variable number in Eq. (1). The critical values are based on Narayan's (2005, p.1987) table.

Table 4 presents the long-term coefficients estimated following the identification of the cointegration relationship between the series. The results showed that an increase of $1 \%$ in imports increases the long-term EF per capita by $0.116 \%$. An increase of $1 \%$ in exports decreases the EF per capita by $0.103 \%$. Clean energy consumption does not affect EF per capita in the long term. The positive value of the coefficient of GDP per capita and the negative value of the coefficient of the square of GDP per capita concluded that the EKC hypothesis is valid in Turkey. In the present study, the turning point value based on the EKC hypothesis was $\$ 16,045$. This value is outside the period of this study's focus. Furthermore, at the end of the CMR unit root test, we obtained the year 2001 and added it to the ARDL model, and the coefficient of that date was negative and statistically meaningful. The 2001 crisis slowed production and economic growth declined in Turkey. Therefore, there has been a decrease in environmental pollution.

Table 4. Long-run coefficients based on ARDL model.

\begin{tabular}{|l|l|l|}
\hline Variables & Coefficients & t-statistics \\
\hline $\mathrm{Y}$ & $8.207 * * *$ & 5.657 \\
\hline $\mathrm{Y}^{2}$ & $-0.424 * * *$ & -5.457 \\
\hline $\mathrm{CEC}$ & 0.030 & 1.455 \\
\hline $\mathrm{EX}$ & $-0.103 * * *$ & -3.185 \\
\hline $\mathrm{IM}$ & $0.117 * * *$ & 3.214 \\
\hline URB & -0.120 & -0.745 \\
\hline $\mathrm{D}_{2001}$ & $-0.08^{* * *}$ & -2.903 \\
\hline $\mathrm{C}$ & $-38.111^{*} * *$ & -6.074 \\
\hline Diagnostic Tests & Test-statistics & p-values \\
\hline BG-LM & 0.016 & 0.902 \\
\hline BPG & 0.772 & 0.630 \\
\hline White & 0.737 & 0.658 \\
\hline ARCH & 0.209 & 0.650 \\
\hline Ramsey Reset & 0.755 & 0.456 \\
\hline
\end{tabular}




\begin{tabular}{|l|l|l|}
\hline Jarque-Bera & 0.238 & 0.888 \\
\hline CUSUM & 0.576 & 0.464 \\
\hline CUSUMSQ & 0.091 & 1.000 \\
\hline
\end{tabular}

*** denotes significant at $1 \%$ level.

Through diagnostic tests on the estimated ARDL model, the Breusch-Godfrey LM (BGLM) test indicated the absence of an autocorrelation problem. The White, Breusch-PaganGodfrey (BGP), and autoregressive conditional heteroskedasticity $(\mathrm{ARCH})$ tests revealed the absence of a heteroscedasticity problem. The Jarque-Bera test demonstrated that the error terms are normally distributed. The Ramsey reset test revealed that the model was built on an appropriate structural form. The results of the CUSUM and CUSUMSQ tests indicated that the coefficients obtained from the model are stable.

Table 5. Error Correction Model Results

\begin{tabular}{|l|l|l|}
\hline Variables & Coefficients & t-statistics \\
\hline$\Delta \mathrm{Y}$ & $9.561 * * *$ & 3.563 \\
\hline$\Delta \mathrm{Y}^{2}$ & $-0.496 * * *$ & -3.347 \\
\hline$\Delta \mathrm{CEC}$ & 0.033 & 0.167 \\
\hline$\Delta \mathrm{EX}$ & $-0.118 * * *$ & -4.471 \\
\hline$\Delta \mathrm{IM}$ & $0.129 * * *$ & 5.105 \\
\hline$\Delta \mathrm{URB}$ & -0.052 & -0.186 \\
\hline $\mathrm{ECT}_{\mathrm{t}-1}$ & $-1.120 * * *$ & -5.871 \\
\hline $\mathrm{D}_{2001}$ & $-0.086 * * *$ & -4.666 \\
\hline $\mathrm{C}$ & $-42.511 * * *$ & -5.785 \\
\hline$* * *$ denotes significant at 1\% level. &
\end{tabular}

Finally, Table 5 presents ECM results based on the ARDL model. Given the short-term coefficients, it is evident that all variables except for clean energy consumption and urbanization affect EF. In the short term, a rise of $1 \%$ in exports decreases EF by $0.118 \%$, whereas an increase of $1 \%$ in import leads to an increase EF by $0.129 \%$.

\section{Conclusions}

This study, by using the ARDL bounds test, tested the validity of the EKC hypothesis in Turkey in the years 1973 to 2015 by using the variables of per capita EF, per capita GDP, per capita clean energy consumption, exports, imports and urbanization. The bounds test found evidence of a cointegration relationship in the series. 
The coefficients obtained from the ARDL model revealed that there was an inverse-U relationship between per capita EF and per capita income in both the long and short terms, thereby validating the EKC hypothesis. The turning point value of $\$ 16,045$ found in the model is outside the relevant period. According to Iwata et al. (2011), there is a probability of finding the turning points out of the sample periods of developing countries. That the turning point value was found to be outside the sample period for Turkey in relation to its status as a developing country is therefore consistent with the results of Bölük and Mert (2015), Tutulmaz (2015), Pata (2018a), Pata(2018b), and Pata (2018c).

In the long term, in addition to the variables in GDP, an increase of $1 \%$ in imports increases the EF per capita by $0.116 \%$ whereas an increase of $1 \%$ in exports decreases the EF per capita by 0.103 . Therefore, the use of domestic raw materials rather than import-oriented growth to increase export value may allow both the narrowing of the foreign trade deficit and the reduction of environmental pollution. An increase of $1 \%$ in clean energy consumption per capita and urbanization had no effect on EF per capita. The fact that clean energy consumption does not affect environmental pollution indicates the proportion of clean energy consumption in comparison to total energy is small. In the short term, imports and export have effect on EF.

The use of environmentally friendly technologies instead of old technologies based on fossil fuel consumption, and the state's support for such practices, is of great importance for sustainable development in Turkey as well as in developing countries generally. Moreover, extending these activities to the long term may contribute to a reduction in costs. Long-term structural reforms are required to use alternative energy sources as substitutes for fossil fuels. Therefore, raising the proportion of renewable energy capacity can be useful in reducing $\mathrm{CO}_{2}$ intensity. 
The CF constitutes the largest share of the EF in Turkey. The main emphasis on the EF is the idea of leaving a protected environment for future generations. For the sustainability of life, policy makers should regulate the living conditions and economic activities of people by considering the carrying capacity of the planet. Therefore, $\mathrm{CO}_{2}$ capture and storage technologies may be used to prevent environmental pollution, and $\mathrm{CO}_{2}$ taxes may be increased to prevent $\mathrm{CF}$. Overcoming the $\mathrm{CF}$ problem would be easier if such activities were regular and stable.

It is predicted that environmental destruction will reduce as GDP per capita increases after the turning point value is exceeded in Turkey. Turkey is a developing country with the 17th largest economy in the world and a goal of becoming a top-10 economy; thus, policymakers have a considerable responsibility to increase income levels by realizing the necessary structural reforms, preventing environmental pollution, ensuring and maintaining sustainable development, and leaving a clean environment for future generations.

\section{References}

Abdallh, AA, Abugamos, H (2017) A semi-parametric panel data analysis on the urbanisationcarbon emissions nexus for the MENA countries. Renewable and Sustainable Energy Reviews, 78, 1350-1356. https://doi.org/10.1016/j.rser.2017.05.006

Al-Mulali, U, Weng-Wai, C, Sheau-Ting, L, Mohammed, A (2015) Investigating the environmental Kuznets curve (EKC) hypothesis by utilizing the ecological footprint as an indicator of environmental degradation. Ecological Indicators 48, 315-323. https://doi.org/10.1016/j.ecolind.2014.08.029.

Ang, JB (2007) $\mathrm{CO}_{2}$ emissions, energy consumption, and output in France. Energy Policy 35(10), 4772-4778. https://doi.org/10.1016/j.enpol.2007.03.032.

Apergis, N, Payne, JE (2012) Renewable and non-renewable energy consumption-growth nexus: Evidence from a panel error correction model. Energy economics, 34(3), 733-738. https://doi.org/10.1016/j.eneco.2011.04.007

Apergis, N, Can, M, Gozgor, G, Lau, CKM (2018) Effects of export concentration on $\mathrm{CO}_{2}$ emissions in developed countries: an empirical analysis. Environmental Science and Pollution Research 25(14), 14106-14116. https://doi.org/10.1007/s11356-018-1634-x

Aşıc1, AA, Acar, S (2016) Does income growth relocate ecological footprint?. Ecological Indicators, 61, 707-714. https://doi.org/10.1016/j.ecolind.2015.10.022

Azlina, AA, Law, SH, Mustapha, NHN (2014) Dynamic linkages among transport energy consumption, income and $\mathrm{CO}_{2}$ emission in Malaysia. Energy Policy 73, 598-606. https://doi.org/10.1016/j.enpol.2014.05.046.

Baek, J (2016) Do nuclear and renewable energy improve the environment? Empirical evidence from the United States. Ecological Indicators 66, 352-356. https://doi.org/10.1016/j.ecolind.2016.01.059. 
Bagliani, M, Bravo, G, Dalmazzone, S (2008) A consumption-based approach to environmental Kuznets curves using the ecological footprint indicator. Ecol. Econ. 65, 650-661. https://doi.org/10.1016/j.ecolecon.2008.01.010

Bello, MO, Solarin, SA, Yen, YY (2018) The impact of electricity consumption on $\mathrm{CO}_{2}$ emission, carbon footprint, water footprint and ecological footprint: the role of hydropower in an emerging economy. Journal of environmental management, 219, 218 230. https://doi.org/10.1016/j.jenvman.2018.04.101.

Ben Jebli, M, Ben Youssef, S, Ozturk, I (2015) The role of renewable energy consumption and trade: environmental Kuznets curve analysis for sub- saharan Africa countries. African Development Review 27(3), 288-300. https://doi.org/10.1111/1467-8268.12147.

Bouznit, M, Pablo-Romero, MDP (2016) $\mathrm{CO}_{2}$ emission and economic growth in Algeria. Energy Policy 96, 93-104. https://doi.org/10.1016/j.enpol.2016.05.036.

Bölük, G, Mert, M (2015) The renewable energy, growth and environmental Kuznets curve in Turkey: an ARDL approach. Renew. Sustain. Energy Rev. 52, 587-595. https://doi.org/10.1016/j.rser.2015.07.138.

Caviglia-Harris, JL, Chambers, D, Kahn, JR (2009) Taking the 'U' out of Kuznets. A comprehensive analysis of the EKC and environmental degradation. Ecological Economics, 68, 1149-1159. https://doi.org/10.1016/j.ecolecon.2008.08.006

Charfeddine, L (2017) The impact of energy consumption and economic development on Ecological Footprint and $\mathrm{CO}_{2}$ emissions: Evidence from a Markov Switching Equilibrium Correction Model. Energy Econ. 65, 355-374. https://doi.org/10.1016/j.eneco.2017.05.009

Charfeddine, L, Mrabet, Z (2017) The impact of economic development and social-political factors on ecological footprint: A panel data analysis for 15 MENA countries. Renew. Sustain. Energy Rev. 76, 138-154. https://doi.org/10.1016/j.rser.2017.03.031.

Chen, Y, Zhao, J, Lai, Z, Wang, Z, Xia, H (2019) Exploring the effects of economic growth, and renewable and non-renewable energy consumption on China's $\mathrm{CO}_{2}$ emissions: Evidence from a regional panel analysis. Renewable Energy 140, 341-353. https://doi.org/10.1016/j.renene.2019.03.058

Clemente, J, Montañés, A, Reyes, M (1998) Testing for a unit root in variables with a double change in the mean. Economics Letters, 59(2), 175-182.

Danish, BZ, Wang, B, Wang, Z (2017) Role of renewable energy and non-renewable energy consumption on EKC: Evidence from Pakistan. Journal of Cleaner Production 156, 855864. https://doi.org/10.1016/j.jclepro.2017.03.203.

Destek, MA, Sarkodie, SA (2019) Investigation of environmental Kuznets curve for ecological footprint: The role of energy and financial development. Science of the Total Environment. 650, 2483-2489. https://doi.org/10.1016/j.scitotenv.2018.10.017

Destek, MA, Sinha, A (2020) Renewable, non-renewable energy consumption, economic growth, trade openness and ecological footprint: Evidence from organisation for economic Co-operation and development countries. Journal of Cleaner Production, 242, 118537. https://doi.org/10.1016/j.jclepro.2019.118537.

Destek, MA, Ulucak, R, Dogan, E (2018) Analyzing the environmental Kuznets curve for the EU countries: the role of ecological footprint. Environmental Science and Pollution Research. 25(29), 29387-29396. https://doi.org/10.1007/s11356-018-2911-4

Galli, A, Wiedmann, T, Ercin, E, Knoblauch, D, Ewing, B, Giljum, S (2012) Integrating ecological, carbon and water footprint into a "footprint family" of indicators: definition and role in tracking human pressure on the planet. Ecological Indicators, 16, 100-112. https://doi.org/10.1016/j.ecolind.2011.06.017

Gill, AR, Viswanathan, KK, Hassan, S (2018) A test of environmental Kuznets curve (EKC) for carbon emission and potential of renewable energy to reduce green house gases 
(GHG) in Malaysia. Environment, Development and Sustainability 20(3), 1103-1114. https://doi.org/10.1007/s10668-017-9929-5.

Global Footprint Network (2019) http://data.footprintnetwork.org/\#/countryTrends?cn= 223\&type $=$ BCpc,EFCpc.

Grossman, GM, Krueger, AB (1991) Environmental impacts of a North American free trade agreement in national bureau of economic research working paper 3914. NBER, Cambridge, MA.

Hossain, $\mathrm{S}$ (2012) An econometric analysis for $\mathrm{CO}_{2}$ emissions, energy consumption, economic growth, foreign trade and urbanization of Japan. Low Carbon Economy 3(3), 92-105. https://doi.org/10.4236/lce.2012.323013.

International Energy Agency (2019) https://www.iea.org/statistics/?country=WORLD\&year= 2016\&category=Energy\%20supply\&indicator=TPESbySource \&mode=chart\&dataTabl $\mathrm{e}=$ BALANCES.

IPCC (2007) Climate change (2007) The physical science basis, contribution of working group I to the fourth assessment report of the intergovernmental panel on climate change, Geneva, Switzerland.

IPCC (2014) Climate change (2014) Synthesis report. contribution of working groups I, II and III to the fifth assessment report of the intergovernmental panel on climate change, Geneva, Switzerland.

Iwata, H, Okada, K, Samreth, S (2011) A note on the environmental Kuznets curve for $\mathrm{CO}_{2}$ : A pooled mean group approach. Applied Energy, 88(5), 1986-1996. https://doi.org/10.1016/j.apenergy.2010.11.005.

Jalil, A, Feridun, M (2011) The impact of growth, energy and financial development on the environment in China: A cointegration analysis. Energy Economics, 33, 284-291. https://doi.org/10.1016/j.eneco.2010.10.003.

Jalil, A, Mahmud, SF (2009) Environment Kuznets curve for $\mathrm{CO}_{2}$ emissions: A cointegration analysis for China. Energy Policy 37(12), 5167-5172. https://doi.org/10.1016/j.enpol.2009.07.044.

Kahia, M, Jebli, MB, Belloumi, M (2019) Analysis of the impact of renewable energy consumption and economic growth on carbon dioxide emissions in 12 MENA countries. Clean Technologies and Environmental Policy 1-15. https://doi.org/10.1007/s10098019-01676-2

Karasoy, A (2019) Drivers of carbon emissions in Turkey: considering asymmetric impacts. Environmental Science and Pollution Research, 26(9), 9219-9231. https://doi.org/10.1007/s11356-019-04354-4.

Kohler, M (2013) $\mathrm{CO}_{2}$ emissions, energy consumption, income and foreign trade: A South African perspective. Energy Policy 63, 1042-1050. https://doi.org/10.1016/j.enpol.2013.09.022.

Menegaki, AN, Tsagarakis KP (2015) Rich enough to go renewable, but too early to leave fossil energy? Renewable and Sustainable Energy Reviews 41, 1465-1477. https://doi.org/10.1016/j.rser.2014.09.038.

Mrabet, Z, Alsamara, M (2017) Testing the Kuznets curve hypothesis for Qatar: A comparison between carbon dioxide and ecological footprint. Renew. Sustain. Energy Rev. 70, 13661375. https://doi.org/10.1016/j.rser.2016.12.039

Munasinghe, M (1999) Is environmental degradation an inevitable consequence of economic growth: Tunneling through the environmental Kuznets curve. Ecological Economics, 29(1), 89-109. https://doi.org/10.1016/S0921-8009(98)00062-7. 
Narayan, PK (2005) The saving and investment nexus for China: evidence from cointegration tests. Applied Economics, 37(17), 1979-1990. https://doi.org/10.1080/00036840500278103.

Nasir, M, Rehman, FU (2011) Environmental Kuznets curve for carbon emissions in Pakistan: An empirical investigation. Energy Policy 39(3), 1857-1864. https://doi.org/10.1016/j.enpol.2011.01.025.

Naz, S, Sultan, R, Zaman, K, Aldakhil, AM, Nassani, AA, Abro, MMQ (2019) Moderating and mediating role of renewable energy consumption, FDI inflows, and economic growth on carbon dioxide emissions: evidence from robust least square estimator. Environmental Science and Pollution Research 26(3), 2806-2819. https://doi.org/10.1007/s11356-018$3837-6$

$\mathrm{Ng}, \mathrm{S}$, Perron, P (2001) Lag length selection and the construction of unit root tests with good size and power. Econometrica, 69(6), 1519-1554. https://doi.org/10.1111/14680262.00256.

Onater-Isberk, E (2016) Environmental Kuznets curve under noncarbohydrate energy. Renewable and Sustainable Energy Reviews. 64, 338-347. https://doi.org/10.1016/j.rser.2016.06.022.

Ozcan, B, Apergis, N, Shahbaz, M (2018) A revisit of the environmental Kuznets curve hypothesis for Turkey: New evidence from bootstrap rolling window causality. Environmental Science and Pollution Research, 25(32), 32381-32394. https://doi.org/10.1007/s11356-018-3165-x

Ozturk, I, Al-Mulali, U, Saboori, B (2016) Investigating the environmental Kuznets curve hypothesis: the role of tourism and ecological footprint. Environ. Sci. Pollut. Res. 23, 1916-1928. https://doi.org/10.1007/s11356-015-5447-x.

Pablo-Romero, MDP, Sanchez-Braza, A (2015) Productive energy use and economic growth: Energy, physical and human capital relationships. Energy Econ. 49, 420-429. https://doi.org/10.1016/j.eneco.2015.03.010

Pao, HT, Tsai, CM (2011) Multivariate Granger causality between CO2 emissions, energy consumption, FDI (foreign direct investment) and GDP (gross domestic product): evidence from a panel of BRIC (Brazil, Russian Federation, India, and China) countries. Energy, 36(1), 685-693. https://doi.org/10.1016/j.energy.2010.09.041

Pesaran, MH, Shin, Y, Smith, RJ (2001) Bounds testing approaches to the analysis of level relationships. Journal of Applied Econometrics 16(3), 289-326. https://doi.org/10.1002/jae.616.

Qiao, H, Zheng, F, Jiang, H, Dong, K (2019) The greenhouse effect of the agriculture-economic growth-renewable energy nexus: Evidence from G20 countries. Science of The Total Environment 671, 722-731. https://doi.org/10.1016/j.scitotenv.2019.03.336

Phillips, PC, Perron, P (1988) Testing for a unit root in time series regression. Biometrika, 75(2), 335-346.

Panayotou, T (1993) Empirical Tests and Policy Analysis of Environmental Degradation at Different Stages of Economic Development. Working Paper WP238 Technology and Employment Programme. International Labor Office, Geneva.

ata, UK (2018a) The effect of urbanization and industrialization on carbon emissions in Turkey: Evidence from ARDL bounds testing procedure. Environmental Science and Pollution Research 25(8), 7740-7747. https://doi.org/10.1007/s11356-017-1088-6.

Pata, UK (2018b) Renewable energy consumption, urbanization, financial development, income and $\mathrm{CO}_{2}$ emissions in Turkey: Testing EKC hypothesis with structural breaks. $\begin{array}{llll}\text { Journal of } & \text { Cleaner } & \text { 770-779. }\end{array}$ https://doi.org/10.1016/j.jclepro.2018.03.236. 
Pata, UK (2018c) The influence of coal and noncarbohydrate energy consumption on $\mathrm{CO}_{2}$ emissions: Revisiting the environmental Kuznets curve hypothesis for Turkey. Energy 160, 1115-1123. https://doi.org/10.1016/j.energy.2018.07.095.

Pata, UK (2019) Environmental Kuznets curve and trade openness in Turkey: Bootstrap ARDL approach with a structural break. Environmental Science and Pollution Research, 1-13. https://doi.org/10.1007/s11356-019-05266-z.

Rafindadi, AA (2016) Revisiting the concept of environmental Kuznets curve in period of energy disaster and deteriorating income: Empirical evidence from Japan. Energy Policy 94, 274-284. https://doi.org/10.1016/j.enpol.2016.03.040.

Rees, WE (1992) Ecological footprints and appropriated carrying capacity: what urban economics leaves out. Environment and Urbanization, 4(2), 121-130. https://doi.org/10.1177/095624789200400212

Sbia, R, Shahbaz, M, Ozturk, I (2017) Economic growth, financial development, urbanisation and electricity consumption nexus in UAE. Economic research-Ekonomska istraživanja, 30(1), 527-549. http://dx.doi.org/10.1080/1331677X.2017.1305792

Shafiei, S, Salim, RA (2014) Non-renewable and renewable energy consumption and $\mathrm{CO}_{2}$ emissions in OECD countries: A comparative analysis. Energy Policy 66, 547-556. https://doi.org/10.1016/j.enpol.2013.10.064.

Shahbaz, M, Bhattacharya, M, Ahmed, K (2017) $\mathrm{CO}_{2}$ emissions in Australia: economic and non-economic drivers in the Long-Run. Applied Economics 49(13), 1273-1286. https://doi.org/10.1080/00036846.2016.1217306.

Soytas, U, Sari, R, Ewing, BT (2007) Energy consumption, income, and carbon emissions in the United States. Ecological Economics 62, 482-489. https://doi.org/10.1016/j.ecolecon.2006.07.009

Sugiawan, Y, Managi, S (2016) The environmental Kuznets curve in Indonesia: Exploring the potential of renewable energy. Energy Policy 98, 187-198. https://doi.org/10.1016/j.enpol.2016.08.029.

Steinfeld, H, Gerber, P, Wassenaar, TD, Castel, V (2006) Livestock's long shadow: Environmental Issues and options, Food and Agriculture Organization of The United Nations, Rome.

Tamazian, A, Chousa, JP, Vadlamannati, KC, (2009) Does higher economic and financial development lead to environmental degradation: evidence from BRIC countries. Energy policy, 37(1), 246-253. https://doi.org/10.1016/j.enpol.2008.08.025.

Tang, CF, Tan, BW (2015) The impact of energy consumption, income and foreign direct investment on carbon dioxide emissions in Vietnam. Energy, 79, 447-454. https://doi.org/10.1016/j.energy.2014.11.033

Tutulmaz, O (2015) Environmental Kuznets curve time series application for Turkey: why controversial results exist for similar models? Renew. Sustain. Energy Rev. 50, 73-81. https://doi.org/10.1016/j.rser.2015.04.184.

Ulucak, R, Bilgili, F (2018) A reinvestigation of EKC model by ecological footprint measurement for high, middle and low income countries. Journal of Cleaner Production. 188, 144-157. https://doi.org/10.1016/j.jclepro.2018.03.191

Wachernagel, Mathis, Rees, William, 1996. Our Ecological Footprint: Reducing Human Impact on the Earth. The New Catalyst Bioregional Series. New Society Publishers.

Wang, Y, Kang, L, Wu, X, Xiao, Y (2013) Estimating the environmental Kuznets curve for ecological footprint at the global level: A spatial econometric approach. Ecol. Indic. 34, 15-21. https://doi.org/10.1016/j.ecolind.2013.03.021

Wiedmann, T, Minx, J (2008) A definition of 'Carbon Footprint'. In: Ecological Economics Research Trends. Nova Science Publishers, Hauppauge, NY, USA (chapter 1, pp. 1-11).

World Bank (2019) http://data.worldbank.org/datacatalog/world-development-indicators. 
World Meteorological Organization (2017) https://library.wmo.int/doc_num.php?explnum id $=4453$

Yilanci, V, Ozgur, O (2019) Testing the environmental Kuznets curve for G7 countries: Evidence from a bootstrap panel causality test in rolling windows. Environmental Science and Pollution Research, 1-11. https://doi.org/10.1007/s11356-019-05745-3

Yilanci, V, Pata, UK (2020) Convergence of per capita ecological footprint among the ASEAN5 countries: Evidence from a non-linear panel unit root test. Ecological Indicators, 113, 106178.

Zambrano- Monserrate, MA, Fernandez, MA (2017) An environmental Kuznets curve for $\mathrm{N}_{2} \mathrm{O}$ emissions in Germany: An ARDL approach. A United Nations Sustainable Development Journal 41(2), 119-127. https://doi.org/10.1111/1477-8947.12122.

Zoundi, Z (2017) $\mathrm{CO}_{2}$ emissions, renewable energy and the Environmental Kuznets Curve, a panel cointegration approach. Renewable and Sustainable Energy Reviews, 72, 10671075. https://doi.org/10.1016/j.rser.2016.10.018.

\section{Declarations}

\section{Ethics approval and consent to participate}

This manuscript does not involve human participants, human data or human tissue.

\section{Consent for publication}

This manuscript does not contain any individual person's data in any form.

\section{Availability of data and materials}

The datasets generated and analysed during the current study are available in the World Development Indicators repository [https://databank.worldbank.org/source/world-development-indicators]

\section{Competing interests}

The authors declare that they have no competing interests

\section{Funding}

There is no funding source to support this manuscript.

\section{Authors' contributions}

The article was written by a single author. 


\section{Figures}

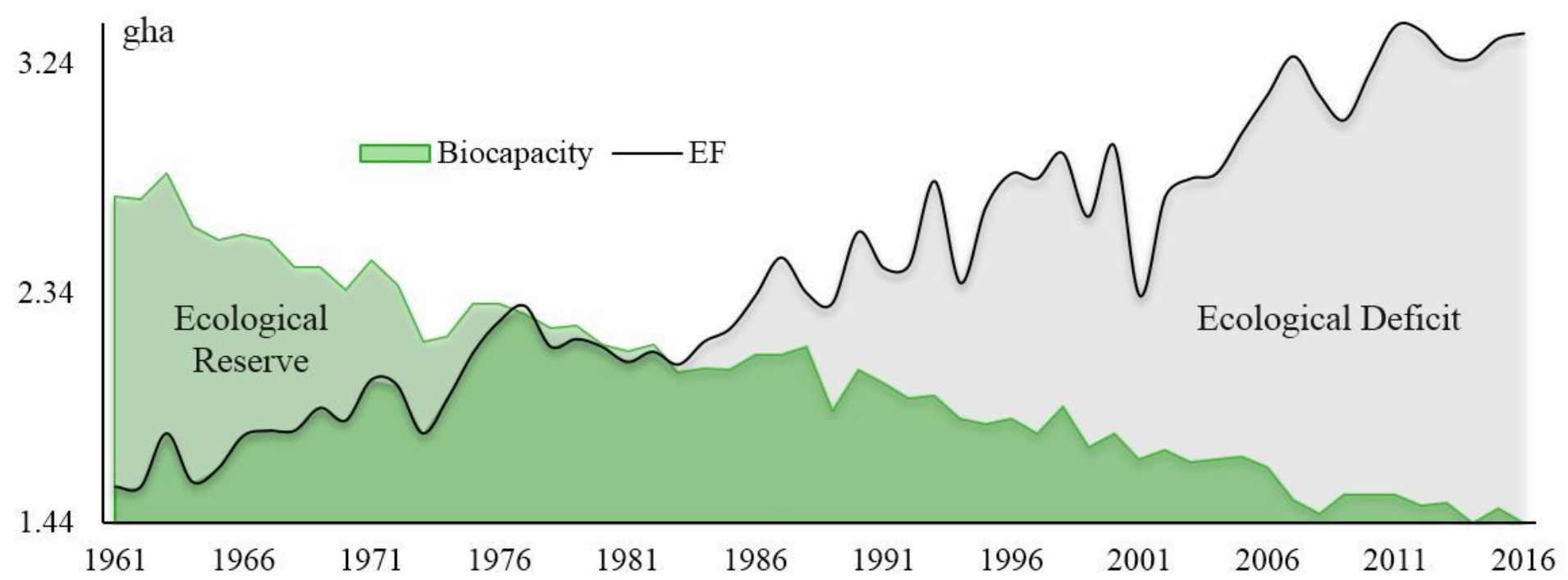

Figure 1

EF and Biocapacity in Turkey.

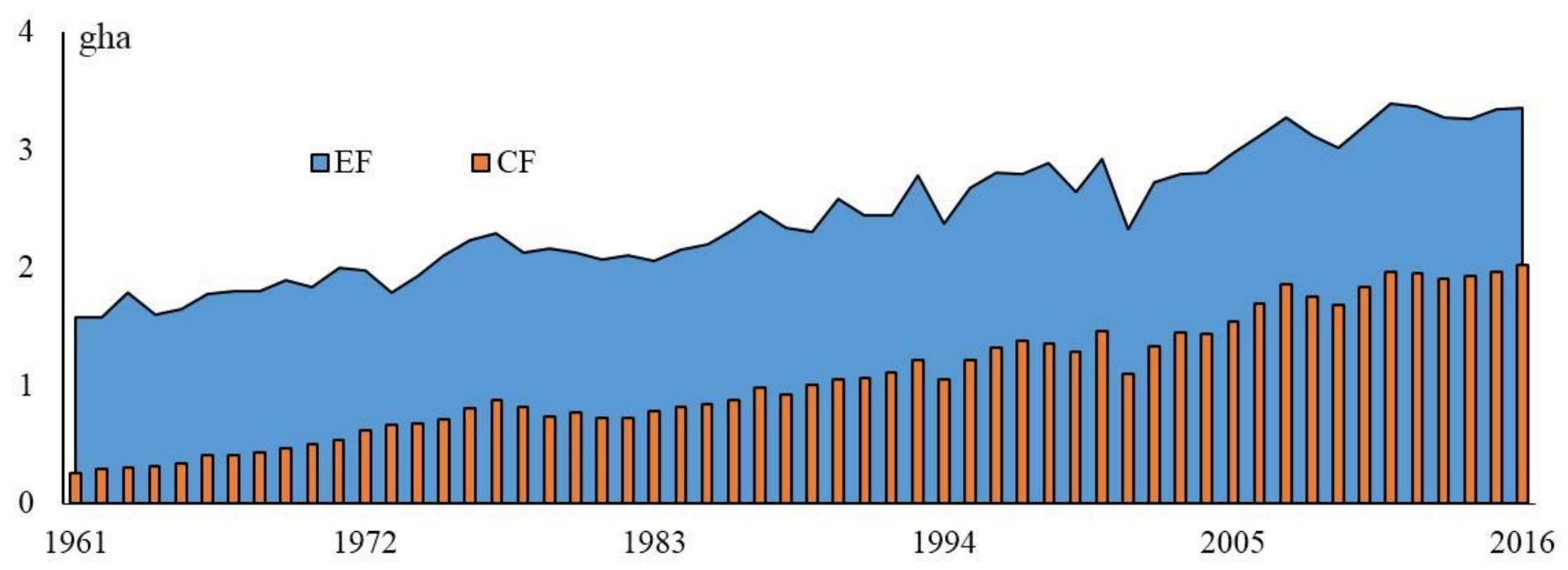

Figure 2

EF and CF in Turkey. 